\title{
$\frac{0 \%}{\text { V.s.u. }}$
}

\section{位相的特徵解析に基づく数值標高モデルの詳細度制御*}

\author{
宮村 (中村) 浩子 ${ }^{1,2}$, 高橋 成雄 $^{3}$, 藤代 一成 ${ }^{4}$ \\ LoD Control of Digital Elevation Models Based \\ on Features of Differential Topology
}

\author{
Hiroko Nakamura Miyamura, Shigeo TAKahashi and Issei Fujishiro
}

\begin{abstract}
In the traditional approaches to the level of detail (LoD) control of polygonal datasets, local features, such as curvature and distance energy, have been used as representative control parameters. However, when our targets are restricted to digital elevation models (DEMs), features of differential topology are expected to play a key role as global features in determining the LoD of these shapes. This paper proposes a novel method of simplifying a given DEM while keeping this kind of features as much as possible. Two sample datasets are used to demonstrate the feasibility of the proposed method.
\end{abstract}

Keywords : Level of detail control, Topological features, Polygonal surface simplification

\section{1. 背景と目的}

近年，コンピュータや計測機器の性能が向上したのに 伴い，さまざまな分野で大規模なデータが扱われるよう になった。しかし，大規模なデー夕を転送したり描画し たりする際には処理に時間を要する。そのため，特徽を 保持しながら要素数を削減するポリゴンデータの詳細度 制御法が盛んに研究されてきている。

詳細度制御法の先行研究では, 与えられたポリゴン データから曲率などの特徴を測定し，その特徴を保存す るようにポリゴンを削減する手法 ${ }^{1)}$ や，元のポリゴン データと詳細度を制御されたポリゴンデータとの距離を 考慮する手法 ${ }^{2)}$ などがある．また，体積を保存する機 能を組み込んだアルゴリズムも提案されている ${ }^{3)}$. 著者 らの先行研究でも, 曲率を基準にして, 形状だけでなく ポリゴンデータの表面にマッピングされた色情報も効果 的に保持する詳細度制御法を提案した ${ }^{4)}$ 。しかし，これ らの手法を用いて数值標高モデルの詳細度を制御する場 合には，局所的な特徵しか考慮されないため，頂上 (peak)・峠（pass）・谷底（pit）を結ぶ尾根線（ridge）・

* 原稿受付 2003 年 10 月 10 日

1 非会員 東京農工大学 大学院生物システム応用科学教育部 （₹ 184-8588＼cjkstart東京都小金井市中町2-24-16, E-mail: miyamura@ cs.tuat.ac.jp)

2 正会員 お茶の水女子大学 大学院人間文化研究科

3 非会員 東京大学 大学院総合文化研究科

4 正会員 お茶の水女子大学 理学部情報科学科 谷線（ravine）によって表現されるような大局的な情報が 失われる抢それがある。尾根線や谷線は, 登山経路や落 水経路を表現し, 尾根線や谷線の経路は等高線に直交し ながら地平面上をトレースするため，これらは数值標高 モデルの特徴を捉える際に重要な役割をもつと考えられ る.

そこで本研究では, 高さ $(z$ 軸) 方向が特別な意味をも つ数值標高モデルから構成されるポリゴンデータの大局 的な特徵を考慮した詳細度制御について検討する。数值 標高モデルは，Digital Elevation Model（DEM）とよば れ, 一価関数 $z=f(x, y)$ で表現される曲面上の頂点から構 成される。われわれはこの DEM から, 特に頂上・峠・ 谷底, 尾根線 - 谷線などの曲面の微分位相幾何学的特徴 を抽出し, ポリゴンデータの詳細度制御に用いる。本手 法の特長は, 先行研究 ${ }^{1)-4)}$ と同様に局所的な形状特徵 をとらえられるだけでなく, 曲面の性質から導かれる大 局的な性質も満たすことである. DEM の多重解像度制御 に関しては, De Floriani らによる研究 ${ }^{5)}$ が知られている が，そこで用いられる形状特徴は局所的な特徴に限られ ている. 本手法では, 詳細度制御に上で述べた微分位相 幾何学的特徵を用いることで, 形状の大局的な構造（骨 組み）を保持したまま局所的特徵の詳細度を制御可能に して㧍り, その点が従来の詳細度制御手法から大きく異 なる。

対象デー夕の大局的な構造を保持することで, 詳細度 を制御したデータから特徵領域を特定する指標となる等 
高線遷移の特徵も効果的に保持できる。これは, 微分位 相幾何学的特徵を考慮しない先行研究 1)-5）を用いて詳 細度を制御する際に，等高線遷移の特徵が崩れることで ユーザが特徴領域を誤って認識する問題を解決する。ま た, 詳細度制御によって削除された要素を必要に応じて 復元する際に，等高線遷移に代表される大局的な構造特 徵を，復元領域の選択に利用できる。ささらに，復元操作 を利用することで，大規模デー夕の段階的転送にも利用 できる。これは，結果画像だけを転送する場合と比べ， クライアントマシン側で対話的に可視化操作ができる利 点につながる.

\section{2. 微分位相幾何学的特徵の解析}

本研究では臨界点（頂上・峠・谷底）と特徵線（尾根 線・谷線）の微分位相幾何学的特徴を用いて地形デー夕 の形状特徴を解析する. 頂上・峠 - 谷底は以下に示すオ イラーの公式を満たすことが必要とされる：

$$
\#\{\text { peak }\}-\#\{\text { pass }\}+\#\{\text { pit }\}=2,
$$

ここでの \#\{peak\},\#\{pass\}，\#\{pit\} はそれぞれ頂上，峠， 谷底である頂点数を表す。なお，このオイラーの公式の 計算に際しては, 地形形状が球面の上方を占めていると 考え，球面の底に対応する谷底を仮想的に加える必要が ある。この仮想的に加えられた谷底を仮想谷底（virtual pit）とよぶ.ささらに, 尾根線・谷線は, それぞれ頂上と 峠, 峠と谷底を結ぶ特徴線を表し，この 2 種類の線が地 形表面上に双対関係をもつ大局的な領域分割を構築する. われわれは，上記のような曲面の大局的な性質を，離散 データからでも頑健に抽出するアルゴリズム ${ }^{6)}$ を用いて 抽出する.

\section{1 地形形状データの特徵抽出}

地形デー夕は， $z$ 軸を高さとしたとき $z=f(x, y)$ で表さ れる地形形状曲面を, $x y$ 平面に関して格子状にサンプリ ングしたものと仮定する。このデータに対して，まず各 サンプル点を頂点とする三角形分割を施す。ここでは, データ依存三角形分割 ${ }^{7)}$ を施すことで, 形状全体が滑ら かになるようにする。

それぞれの頂点について，三角形分割のリンクで直接 接続する隣接点を求め, その高さを比較することで臨界 点を抽出する。具体的には, すべての隣接点が対象とな る頂点より低い場合，その頂点は頂上と判定され (Fig. 1 (a)), 逆に高い場合は谷底と判定される (Fig. $1(\mathbf{b}))$. 峠は，対象となる頂点に関して隣接点を一巡するように 比較したときに，頂点より高い点列と低い点列が 2 回ず つ交互に現れるものとして抽出される（Fig. 1(c)).

次に抽出された臨界点から, 特徴線を抽出する.まず 尾根線は，抽出された各峠に対し，上で述べたような高 い隣接点列それぞれから，一番高い点である代表点を選 び出し，これらの点を出発点として頂上へ単調に上昇す る $\mathrm{DEM}$ 上の経路として求めることができる，谷線は，
逆に谷底に行き着くまで単調に降下する経路を求めれば よい。このようにして，臨界点を特徴線で結んだグラフ をサーフェイスネットワークとよぶ ${ }^{8)}$. Fig. 1 (c) では, 対象頂点より高い点列 $\left\{P_{1}, P_{5}, P_{6}\right\},\left\{P_{3}\right\}$ からそれぞれ 一番高い頂点 $P_{5}, P_{3}$ を通るような尾根線が抽出され，同 様に $P_{2}, P_{4}$ を通るような谷線が抽出される. Fig. 2 は, サーフェイスネットワークのリンク（実線）を等高線 (破線) と一緒に表示した例である. 矢印は下り方向を示 している。このようにして，サーフェイスネットワーク は地形表面の尾根線と谷線の配置を効果的に表現できる. 実際の地形データからサーフェイスネットワークを抽 出した結果を Fig. 3 に示す. 箱根・芦ノ湖周辺の地形 データ（Fig. 3(a)）からサーフェイスネットワークを構 築する (Fig. 3(b))。ただし, Fig. 3(b) では仮想谷底,

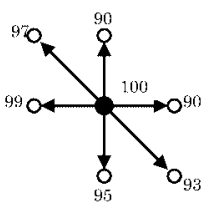

(a) peak

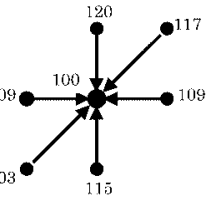

(b) pit

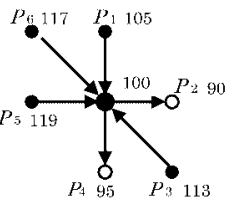

(c) pass
Fig. 1 Classification of critical points.

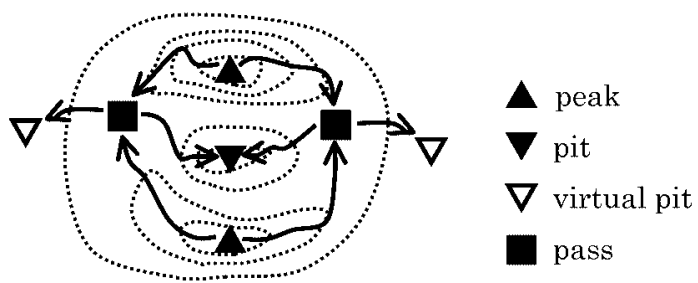

Fig. 2 Surface network and contour lines.
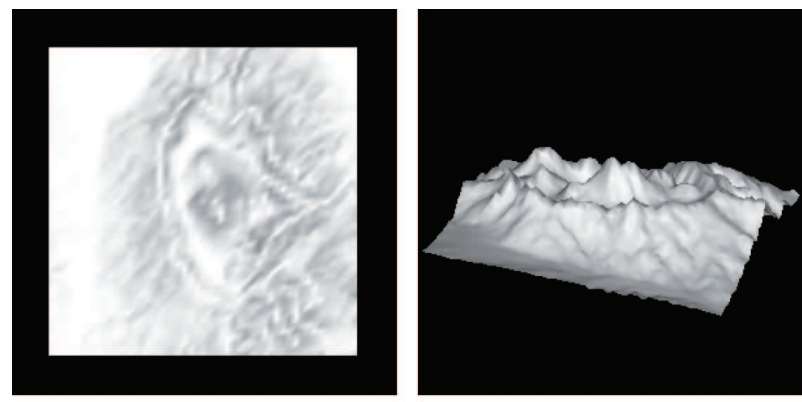

(a) Original DEM data
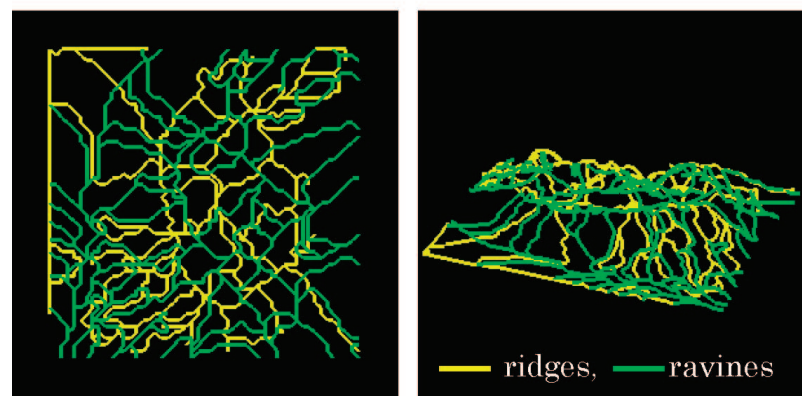

(b) Surface network

Fig. 3 Surface network of the Hakone area. 
および仮想谷底へ接続する谷線は表示していない.ここ でのサンプル点総数は $2,601 （=51 \times 51 ）$ 個であり，そ の中で頂上として抽出された頂点は 29 個, 谷底は 69 個, 峠は 96 個である。この解析結果から式(1)に示すオイ ラーの公式を満たしていることが確認できる。尾根線, 谷線はともに 190 本抽出された.

\section{2 スカラデータの特徴抽出}

2 次元画像のような $x y$ 座標上にスカラ值が与えられた スカラデータに関しても，スカラ值を高さ関数とみなす ことで DEM として扱うことができ，サーフェイスネッ トワークを構築できる.

ここでは, 竜巻の風速を表す 3 次元スカラ場を用いて 説明する。対象データは， $64 \times 64 \times 64$ の規則格子ボ リュームデータであり，Fig. 4 (a) はそこからある等風 速值面を抽出した結果である. 3 次元ボリュームデー夕 を詳細に観察する際には，しばしば Fig. 4(b) に示すよ うな 2 次元断面画像が複数枚用いられる。 Fig. 4 (b) は $x y$ 平面に対して水平方向に抽出した断面上の風速值を擬 似カラーコーディングしており，抽出された断面位置で の風速の分布状態を把握できる。この断面画像の微分位 相幾何学的特徴を解析するために，まず，風速值をハイ トフィールドとみなし Fig. 4(c) に示すような一価関数 で表現される曲面データを得る。そして，このデータか らサーフェイスネットワークを構築する（Fig. 4 (d)).

Fig. 4 (d) では，仮想谷底，および仮想谷底へ接続する 谷線は表示していない。ここでのサンプル点総数は 4,096 $(=64 \times 64 ）$ 個であり，その中で頂上として抽出された頂

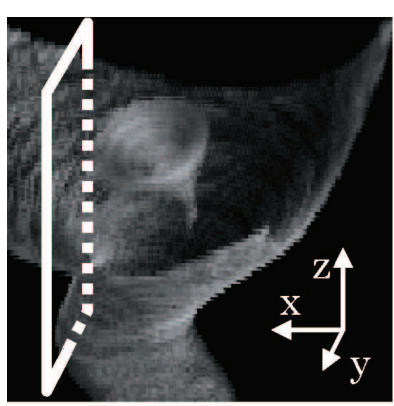

(a) Original scalar data

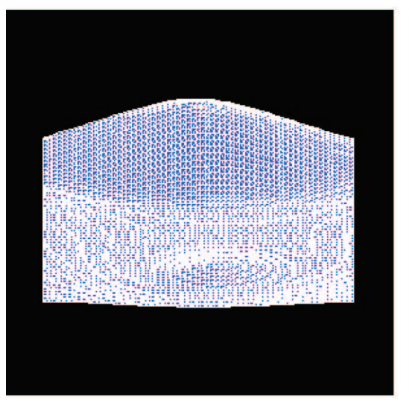

(c) Cross section (height: wind velocity)

Fig. 4 Surface network of a tornado numerical model.
点は 6 個, 谷底は 18 個, 峠は 22 個である. 前節の地形 データ同様，式(1)のオイラーの公式を満たしている。な お，尾根線，谷線はともに 44 本抽出された。

\section{3．位相的特徵を考慮した詳細度制御}

尾根線や谷線のような微分位相幾何学的特徵を考慮す るために, 曲面内部の稜線特徵を捉えながらサーフェイ スポリゴンデータの詳細度を制御するデシメーションア ルゴリズム (Decimation Algorithm: DA) ${ }^{1)}$ を拡張する. DA は, 頂点に接続する三角形パッチの状態から, 頂点 近傍での幾何学的特徴を測定し, この特徵を効果的に保 ちながら要素数を削減する。DA を拡張することで，微分 位相幾何学的特徵で表現される大局的な特徽だけでなく, 局所的な幾何学的特徵も併せて保持できる.

\section{1 デシメーションアルゴリズム}

1992 年に Schroeder らによって提案された $\mathrm{DA}^{1)}$ では, 以下のステップに従って形状的に重要な特徵を保ちなが ら 3 次元ポリゴンデータの詳細度を制御する：

ステップ 1 : 頂点を隣接要素の状態から以下の 5 つに分

類 (Fig. 5 上)

- simple : パッチが一巡

- interior edge : 特徵稜線が 2 本接続

- corner : 特徵稜線が 1 , または 3 本以上接続

- complex : 交差するパッチが存在

-boundary：境界稜線が接続

ステップ 2 : 分類された頂点に対して，分類ごとに以下

に示す距離誤差 $d$ を測定し, 形状特徵を評価

- simple, corner：頂点に接続する要素のアベレージ 平面と頂点の距離 $d$. アベレージ平面は次式で与 えられる：

法線: $\vec{N}=\frac{\vec{n}_{i} A_{i}}{A_{i}}$, 平面上の点 : $\bar{x}=\frac{\vec{x}_{i} A_{i}}{A_{i}}$

$\left(\vec{n}_{i}, A_{i}, \vec{x}_{i}\right.$ はそれぞれ隣接要素 $i$ の法線, 面積, 重心)

- boundary, interior edge：境界線や鋭角線の端点に よって生成される直線と頂点の距離 $d$

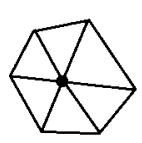

simple

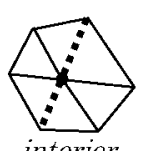

interior edge

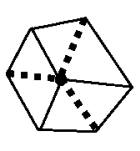

corner

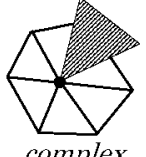

complex
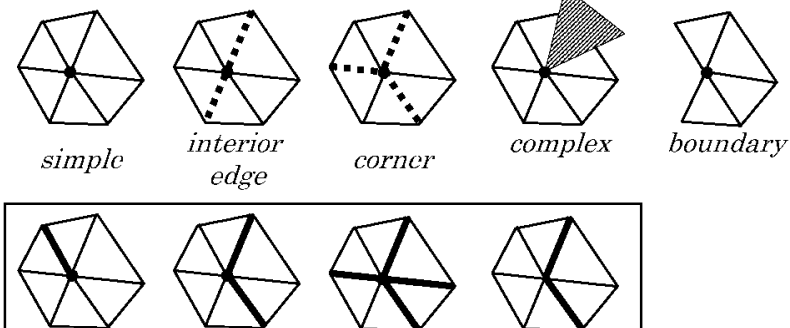

peak

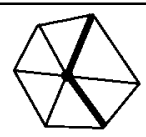

pit

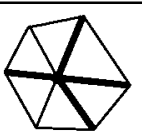

pass
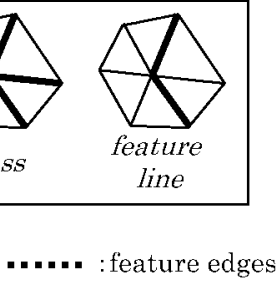

:ridges and ravines

Fig. 5 Extended classification of vertices in polygonal decimation. 
ステップ 3 : ステップ 2 で求めた形状特徵 $d$ が小さい頂 点を削除し, 再三角形化

ここでの特徵稜線とは, 隣接する 2 つのパッチの外向き 法線がなす角度が，ユーザによって指定された一定角度 以上である稜線のことをさす。本論文中の実験では，経 験的に， $\pi / 3$ 以上の稜線を特徵稜線とする。 また， complex は形状的特徵が大きいので, 削除の対象とはならな い. 以上のステップにそった処理を，減少割合や形状変形 などで表れる誤差許容量によってユーザが定めた限界に 達するまで, 頂点削除の基準を緩和させながら繰り返す.

\section{2 位相的特徵を考慮した詳細度制御}

DA では局所的な稜線の特徵を保持しながらポリゴン データの詳細度を制御する。われわれは，大局的な特徵 をもつ稜線にも着目し，DA では失われる微分位相幾何学 的特徵を考慮する。実際 DA に以下の処理を加えること により解析された微分位相幾何学的特徴の特徵を保持し ていく:

- 頂点分類前に, 以下に示す 4 種類を追加し (Fig. 5 下), これらに分類されない頂点は従来の DA の分類を使用 -peak：頂上

- pit : 谷底

- pass：峠

-feature line: 特徵線が 2 本接続する頂点. サーフ エイスネットワークの尾根線, 谷線上に存在

・特徴線が接続する頂点を削除するときは, 特徵線を直 線近似するように稜線縮退 (edge collapse) を実行 ${ }^{2)}$ (Fig. 6)

・特徵線以外の稜線は, Delaunay 三角形パッチ ${ }^{10)}$ を満 たすように稜線交換 (edge swap) 操作 ${ }^{9)}$ で均等化

(Fig. 6)

位相特徴の解析によって抽出された臨界点を完全に保存 することも可能であるが，臨界点が多数抽出された場合 にはユーザが指定した減少割合に到達しないことがある. そのような場合には，以下に示す重みの小さい pass を削 除の対象とする。

$$
W=f\left(P_{1}\right)+f\left(P_{2}\right)-f\left(P_{3}\right)-f\left(P_{4}\right),
$$

ここで, $f\left(P_{1}\right), f\left(P_{2}\right)$ は pass に接続する 2 本の尾根線の接 続頂点 $P_{1}, P_{2}$ の標高值を表し, $f\left(P_{3}\right), f\left(P_{4}\right)$ は pass に接 続する 2 本の谷線の接続頂点 $P_{3}, P_{4}$ の標高值を表す. pass を削除の対象に組み入れることで, 式 (1)に示すオイ ラーの公式を満たすようにpeak または pit が臨界点とし ての特徴を失う。臨界点としての特徴を失った頂点は削 除の対象に加えられる。例えば Fig. 7 では, 頂点 $P_{2}$ は pass に分類されるが (2.1 節参照), この頂点を削除し, 稜線 $\left(P_{1}, P_{2}\right)$ を縮退させると, もともと pit に分類され ていた頂点 $P_{1}$ が pit ではなくなり, 削除の対象とされる. これは, $P_{1}$ の pit として特徴が $P_{3}$ の pit の特徴に吸収さ れたことを意味する。

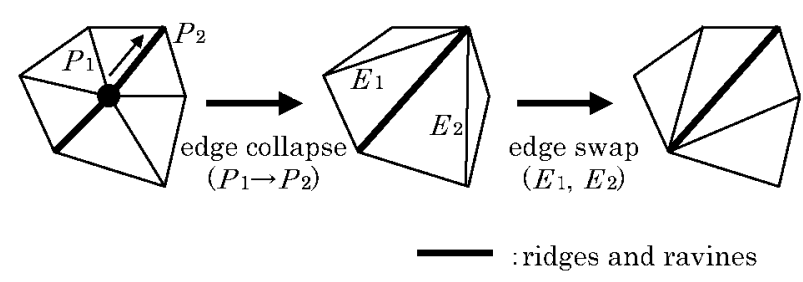

Fig. 6 Edge collapse and edge swap by taking feature edges into account.

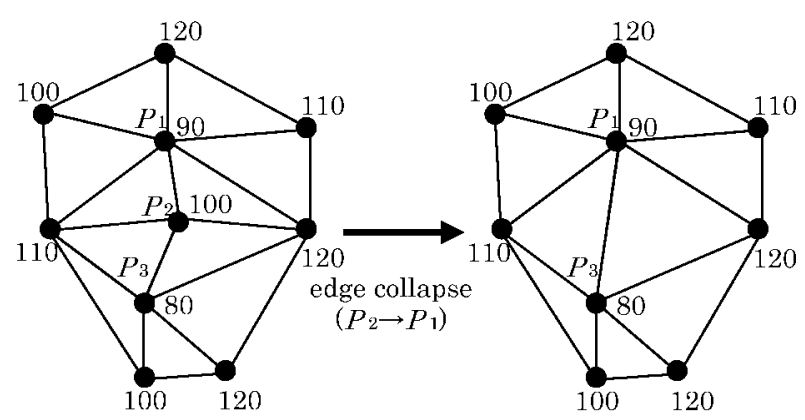

Fig. 7 An example where features of differential topology are lost by removing a pass.

\section{3 詳細度制御による特徴損失量の評価}

ポリゴンデータの詳細度制御法の精度を比較・検討す るために, 詳細度制御で要素数を削減したことによって 失われた特徴を定量的に評価する必要がある。そこで, 既存の形状特徵損失量に加えて, 新たに微分位相幾何学 的特徴損失量を定義し, それぞれを評価する. 形状特徴 損失量では, 詳細度が制御されたサーフェイスポリゴン データ $S^{\prime}$ 上の頂点 $P^{\prime}$ から元のサーフェイスポリゴン デー夕 $S$ までの距離を求める。この距離を, 元デー夕を含 む矩形領域の最長辺の長さ $d_{\mathrm{box}}(S)$ で割ることにより正規 化したものの和を形状特徵損失量 $E_{\text {shape }}\left(S^{\prime}\right)$ とする ${ }^{11)}$ :

$$
E_{\text {shape }}\left(S^{\prime}\right)=\sum_{P^{\prime} \in S^{\prime}}\left(\frac{\min _{P \in S}\left\|P-P^{\prime}\right\|}{d_{b o x}(S)}\right),
$$

微分位相幾何学的特徵損失量 $E_{\text {critical }}\left(S^{\prime}\right)$ については, サーフェイスネットワークの変化量や, 臨界点分布の変 化量などで表せる。ここでは，位相特徴の解析によって 抽出された臨界点を完全に保存したときに特徴損失量が 0 になるように, 削除した臨界点数と臨界点としての特徵 を失った頂点数の割合で表現し，新たに臨界点の性質を 得た頂点数はカウントしない. 元データの微分位相幾何 学的特徴解析によって抽出された臨界点群（\#\{critical $\}$ ) の中で, 詳細度制御処理によって削除された峠の数 (\#\{lost_pass $\})$ と峠を削除したことによって臨界点として の性質を失った臨界点の数（\#\{lost_critical $\} ）$ の割合を求 める :

$$
E_{\text {critical }}\left(S^{\prime}\right)=\frac{w_{1} \#\{\text { lost_pass }\}+w_{2} \#\{\text { lost_critical }\}}{\#\{\text { critical }\}},
$$

ここでは, 削除した臨界点と, 臨界点としての特徴を失っ た頂点の重みを等しくするために $w_{1}=w_{2}=1$ とする. 


\section{4 復 元}

頂点，および三角形パッチを削除する稜線縮退化操作 の逆操作である頂点分割（vertex split）操作 (Fig. 8) ${ }^{2)}$ によって，データを元の状態に戻す．削除される頂点と その縮退先の頂点，さらに縮退先の両脇の頂点 ID を削除 履歴情報として保存する. Fig. 8 では， $\left(P_{1}, P_{2}, P_{3}, P_{4}\right)$ を削除履歴情報として保存する．完全に復元するために， 削除された頂点の 2 次元空間内の座標值，および高さ （スカラ值）も保存する．削除履歴情報を用いて復元する には， $P_{2}$ から反時計回りに接続頂点をたどったときに， $P_{3}$ と $P_{4}$ にはさまれる三角形パッチの頂点 $P_{2}$ を $P_{1}$ に移動 し, さらに三角形パッチ $\left(P_{1}, P_{2}, P_{3}\right),\left(P_{2}, P_{1}, P_{4}\right)$ を新 しく作成する。このデー夕格納を利用すると，三角形 パッチ $\left(P_{1}, P_{2}, P_{3}\right),\left(P_{2}, P_{1}, P_{4}\right)$ を削除履歴情報である $\left(P_{1}, P_{2}, P_{3}, P_{4}\right)$ で置き換えることができる.

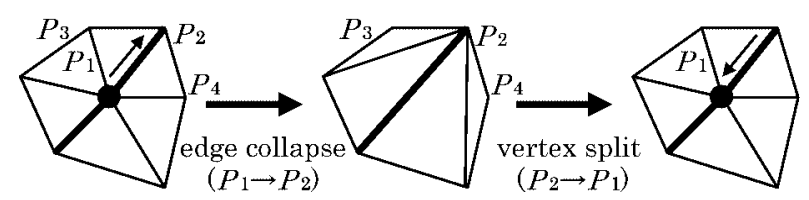

Fig. 8 Edge collapse and vertex split.

\section{4. 実験}

提案手法を用いて，局所的な形状特徴に加えて微分位 相幾何学的特徵を考慮して詳細度を制御した。実験には, 2 章で示した地形データとスカラデータを用いた。実 装・実験環境には，SGI 社製 O2 システム（CPU： R10000, Clock : 180MHz，RAM：192MB）を使用した。 提案手法を DA と DEM の多重解像度制御 (Hierarchical Triangulation: HT ${ }^{5)}$ と比較した結果も示す.HT では, 粗い三角形パッチとその領域内の元データ頂点との距離 を測定し，その距離が大きい頂点を挿入し，細かい三角 形パッチ群に分割する。

\section{1 地形データの詳細度制御}

地形データの詳細度制御実験には, Fig. 3 に示した箱 根・芦ノ湖周辺の地形データを用いた。箱根・芦ノ湖周 辺の地形データと, その臨界点分布図を Fig. 9(a) に示 す。ここでは, 元データで頂上, 峠, 谷底として抽出され た頂点をそれぞれグリフで表示している。この地形デー 夕に対して臨界点, 特徴線の形状特徴を保持しながら三 角形パッチ数を $75 \%$ 削減した結果を Fig. 9(b) に示す. 次に，本手法と，DA で詳細度を制御した結果（Fig. 9 （c））を比較する．本手法は DA と比べ，凹凸のような局 所的な形状特徵に加えて, 頂上・峠 - 谷底, 尾根線 - 谷 線として認識される大局的な形状特徴も保持できている ことが確認できる，HTでは，元データで隣接パッチの 成す角が鋭角であるような稜線が残るため，形状特徴を 精密に表現できるが, DA と同様に微分位相幾何学的特徵 損失量は大きくなる $($ Fig. 9 (d)).

3 章で定義した形状特徵損失量, 微分位相幾何学的特 徵損失量をそれぞれの結果から測定した值を Table 1 に 示す。さらに, 地形データの詳細度を制御するのに要し た時間を 3.1 節のステップごとに計測した。位相解析に 要した時間 $\left(T_{\text {topology }}\right)$ もそれぞれ示す。提案手法では,

Table 1 Errors and timings (cpu seconds) in simplifying the geographical data in Fig. 9.

\begin{tabular}{|c|c|c|c|c|}
\hline & & Present & DA & $\mathrm{HT}$ \\
\hline \multicolumn{2}{|c|}{ Reduction } & $75 \%$ & $75 \%$ & $75 \%$ \\
\hline \multirow{2}{*}{ م) } & $E_{\text {shape }}$ & $5.33 \times 10^{-2}$ & $5.52 \times 10^{-2}$ & $3.21 \times 10^{-2}$ \\
\hline & $E_{\text {critical }}$ & $5.57 \times 10^{-1}$ & $7.42 \times 10^{-1}$ & $7.11 \times 10^{-1}$ \\
\hline \multirow{5}{*}{ 节. } & Step 1 & 0.105 & 0.290 & - \\
\hline & Step 2 & 0.306 & 0.136 & - \\
\hline & Step 3 & 0.560 & 0.438 & - \\
\hline & $T_{\text {topology }}$ & 0.166 & - & - \\
\hline & Total & 2.24 & 2.06 & 6.11 \\
\hline
\end{tabular}

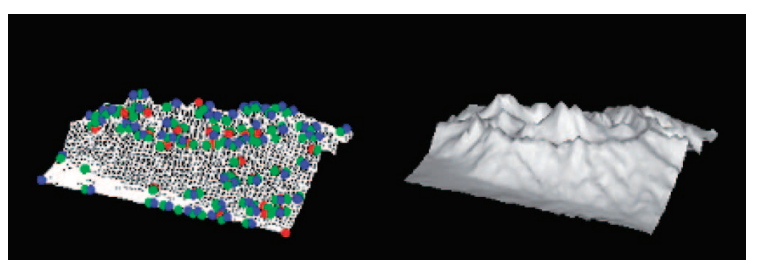

(a) Original data

(Vertices: 2,601; Patches: 5,000)

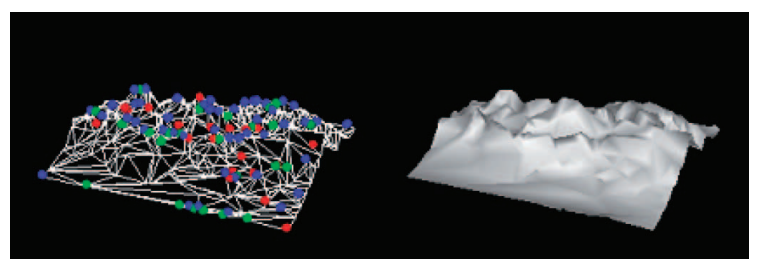

(c) Decimation algorithm

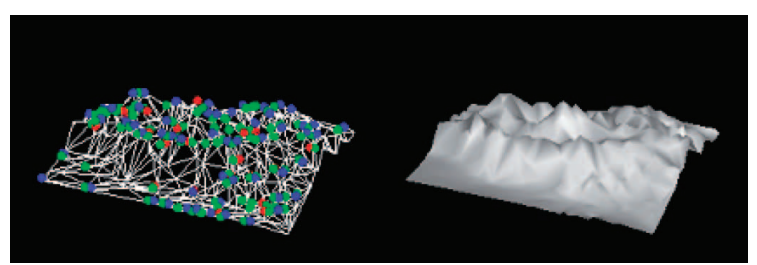

(b) Present algorithm

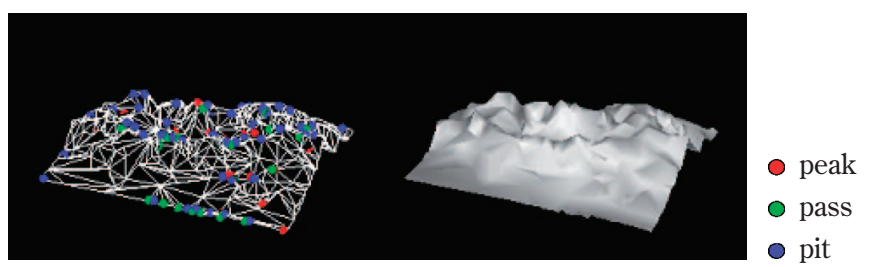

(d) Hierarchical triangulation

Fig. 9 Simplifying the geographical data of the Hakone area (reduction ratio: 75\%). 
位相解析に時間を要するが, 位相解析時にpeak, pit, pass, feature line が特定できるため, DA でのステップ 1 に要する時間が短縮される。しかし，feature line に分類 された頂点は，尾根線，谷線を直線近似するため，特徵 量測定に時間を要する。計算時間をトータルで比較した ときには，ほぼ同等の時間で詳細度を制御できる。

\section{2 スカラデータの詳細度制御}

風速值（０から 255） が与えられた竜巻の流れ場の 3 次元構造を表すボリュームデータから水平方向に抽出さ れた断面の一枚を実験に用いた。断面上の頂点は 2 から 218 までの風速值をスカラデータとしてもつ. 風速值を高 さ関数にとることでサーフェイスネットワークを構築し た. Fig. $10(\mathrm{a})$ に風速の臨界点分布図，等值線図，擬似 カラーコーディングした図を示す。ここでは，元データ で頂上，峠，谷底として抽出された頂点をグリフで表示 している。サーフェイスネットワークは，元データの風 速值を高さ関数にとることで構築した。抽出された臨界 点, 特徵線を保つことを誤差許容量として設定しながら 三角形パッチを削減した結果を Fig. 10（b）に示す。DA では, 誤差許容量指定にアベレージ平面との距離 $d(3.1$ 節）を利用し， $d$ がスカラデータ幅の $1 / 10$ 以下であるこ とを誤差許容量として詳細度を制御した $($ Fig. 10 (c) ) 。 DA で詳細度を制御したことによって，断面上の最大風速 值は 217 となった。提案手法では最大值をもつサンプリ ング点は頂上として定義され，保存される．HT での誤差 許容量には，新しく生成される三角形パッチの隣接パッ チ間の外向き法線の成す角が $10^{\circ}$ 以下と指定して詳細度 を制御した（Fig. 10(d)).ただし，ここでは正規化した スカラデータを高さ関数に用いた。 DA と同様に，微分 位相幾何学的特徵である大局的な構造が失われる。

スカラ值を高さ方向に置き換えたときの形状特徴損失 量, 微分位相幾何学的特徴損失量をそれぞれ Table 2 に
Table 2 Errors and timings(cpu seconds) in simplifying the scalar data in Fig. 10.

\begin{tabular}{|c|c|c|c|c|}
\hline & & Present & $\mathrm{DA}$ & $\mathrm{HT}$ \\
\hline \multicolumn{2}{|c|}{ Reduction } & $99 \%$ & $99 \%$ & $99 \%$ \\
\hline \multirow{2}{*}{ ?7} & $E_{\text {shape }}$ & $3.36 \times 10^{-1}$ & $4.22 \times 10^{-1}$ & $3.12 \times 10^{-1}$ \\
\hline & $E_{\text {critical }}$ & 0.0 & $9.57 \times 10^{-1}$ & $9.35 \times 10^{-1}$ \\
\hline \multirow{5}{*}{ جٍ: } & Step 1 & 0.0625 & 0.110 & - \\
\hline & Step 2 & 0.0622 & 0.0799 & - \\
\hline & Step 3 & 0.575 & 0.666 & - \\
\hline & $T_{\text {topology }}$ & 0.269 & - & - \\
\hline & Total & 1.31 & 1.55 & 3.50 \\
\hline
\end{tabular}

示す.さらに, スカラデータの詳細度を制御するのに要 した時間を 3.1 節のステップごとに示す．スカラ值を高 さ方向に置き換えてから微分位相幾何学的特徴を解析す るのに要した時間もそれぞれ示す，提案手法では，位相 解析に時間を要するが，ステップ 1 に要する時間が短縮 される。

\section{3 特徵領域の特定効果}

竜巻デー夕を擬似カラーコーディングする際の伝達関 数を変えて可視化した結果を示す (Fig. 11). 伝達関数を 変更することによって，同一の対象データからさまざま な情報を得ることができ，興味ある領域を効果的に観察 することができる．Fig. $11(\mathbf{a})$-（d）では上側の渦に注 目した伝達関数を用いて可視化し，Fig. $11(\mathrm{e})$-(h) で は下側の渦に注目した伝達関数を用いて可視化した。提 案手法は, 形状の大局的な構造を保持するため, 伝達関 数の変化に対して頑強に特徴を保持できていることがわ かる.

さらに，一度削減された要素を復元することを考える。 提案手法では, 微分位相幾何学的特徵を保存しているた

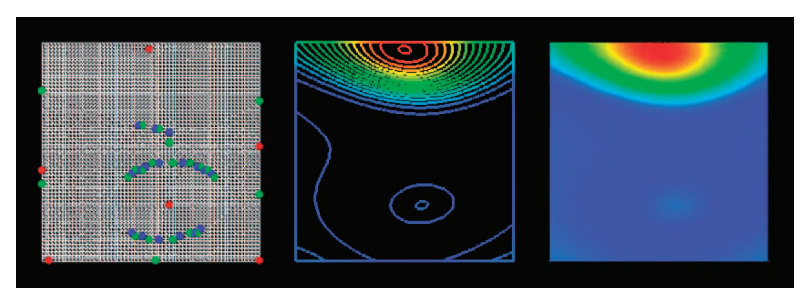

(a) Original data

(Vertices: 4,096; Patches: 7,938)

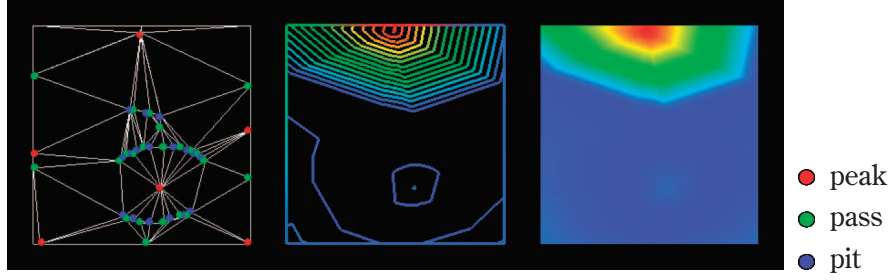

(b) Present algorithm

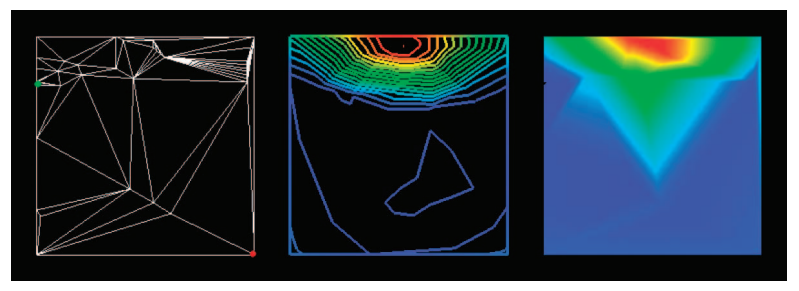

(c) Decimation algorithm

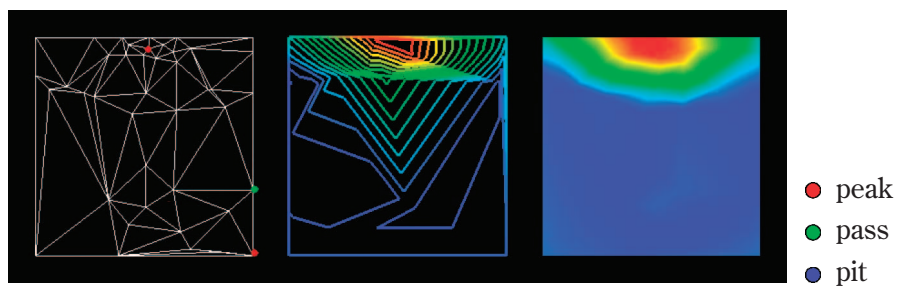

(d) Hierarchical triangulation

Fig. 10 Simplifying the scalar data of a tornado numerical model (reduction ratio: 99\%). 


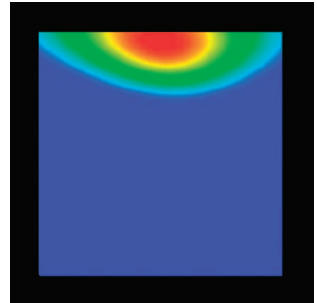

(a) Original data

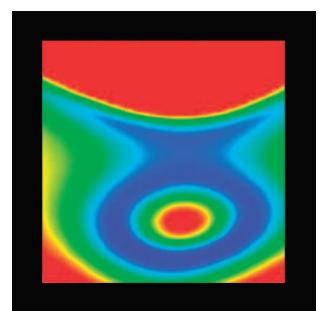

(e) Original data

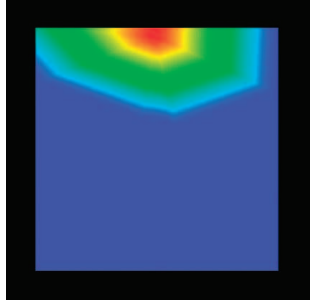

(b) Present algorithm

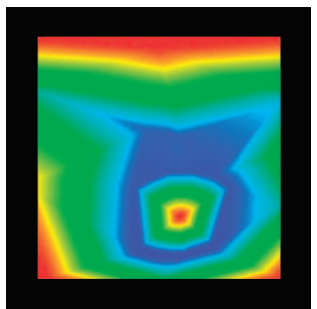

(f) Present algorithm

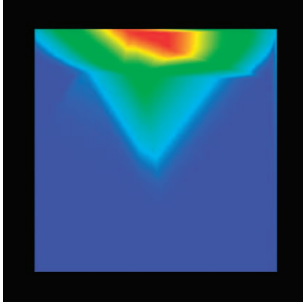

(c) DA

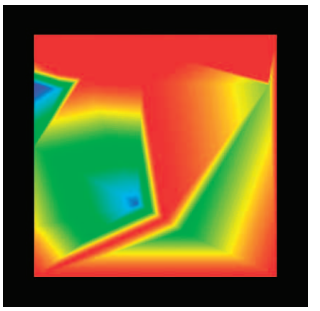

(g) DA

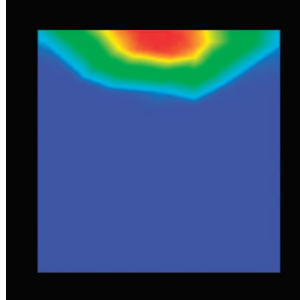

(d) HT

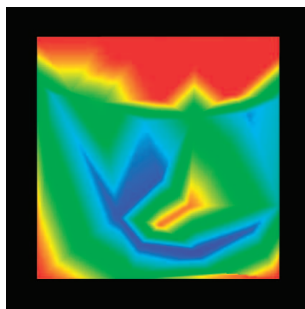

(h) HT

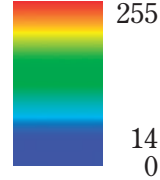

wind velocity

Fig. 11 Simplifying the scalar data of tornado numerical model. Different transfer functions are used to locate the upper vertex structure in (a)-(d) and the lower vertex structure in (e)-(h).

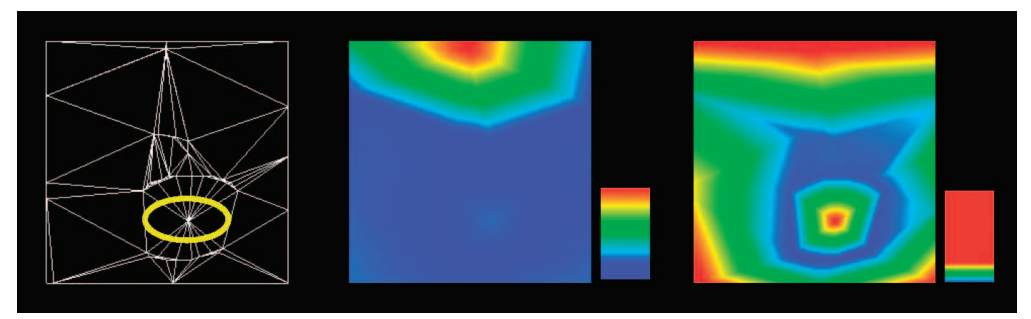

(a) Simplified data

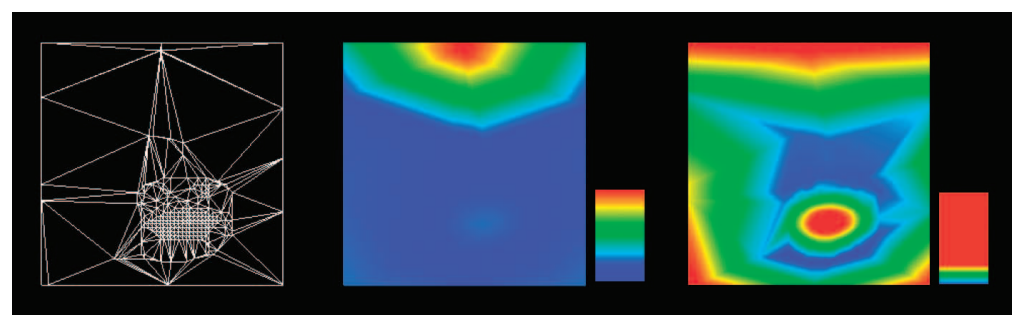

(b) Restructuring a portion of the simplified data

Fig. 12 Partial restructuring from the simplified data in Fig. 10 (b).

め，興味ある領域を指定しやすい. Fig. 12 (a) 中の楕円 枠内を復元した結果を Fig. 12(b) に示す.

\section{5. まとめと今後の課題}

一価関数 $z=f(x, y)$ で表現される曲面上の頂点から構成 される数值標高モデルに対し，微分位相幾何学的な特徴 を抽出し，これらの特徴を保持するポリゴンデータの詳 細度制御法を提案した。局所的な形状的特徵と，微分位 相幾何学的特徵の双方を制御基準に組み込むことで，地 形形状の大局的な構造を保持したまま局所的特徽の詳細 度を制御できた。 また， 2 次元断面上のスカラ值を高さ方 向に置き換えて本手法を適用し，その効果を確認した。 等高線や等值領域などの特徵そのものを画像として転送 する場合 ${ }^{12)}$ と比較して，本手法はスカラデー夕を数值標 高モデル化し, 詳細度を制御するため, クライアントマ
シン側で対話的に可視化操作ができる。さらに，頂点間 の接続関係を保ったまま転送するため，不規則格子デー 夕を扱う際にも有効である。なお，処理時間はDA で詳 細度を制御するのに要した時間に対して $15 \%$ 未満に抑え られた。

今後は, 対象データの次元を上げ，3 次元ボリューム データに適用できるように拡張することを目指す。先行 研究で提案されている 3 次元ボリュームデー夕の詳細度 制御法は，頂点に与えられたスカラ值の周辺における勾 配から特徴の大小を決定している ${ }^{13,14)}$. しかし, ボ リュームレンダリングする際に用いる伝達関数を変える たびに特徴量が変化するという問題が生じる。そこで, スカラ值勾配の大局的な変化を表す微分位相幾何学的特徴 を用いることにより，この問題を解決することを目指す. 


\section{謝辞}

本論文で使用した竜巻データの生成プログラムを提供 してくれた米国オハイオ州立大学の R. Crawfis 氏に深謝 する。

\section{参 考文献}

1 ) Schroeder, W.J., Zarge, J.A., and Lorensen, W.E.: Decimation of Triangle Meshes, In Proc. SIGGRAPH '92, Chicago (1992) pp. 65-70.

2 ) Hoppe, H.: Progressive Meshes, In Proc. SIGGRAPH 96, New Orleans (1996) pp. 99-108.

3 ) Gueziec, A.: Surface Simplification with Variable Tolerance, In Proc. Annual International Symposium on Medical Robotics and Computer Aided Surgery (1995) pp. 132-139.

4 ）中村浩子，竹島由里子，藤代一成，奥田洋司：「形状／色分布 特徵を考慮した区間型ボリュームの半自動詳細度制御」, 情 報処理学会論文誌, Vol. 42, No. 5 (2001) pp. 1115-1123.

5 ) De Floriani L., and Puppo, E.: Hierarchical Triangulation for Multiresolution Surface Description, ACM Transactions on Graphics, Vol. 14, No. 4 (1995) pp. 363-411.

6 ) Takahashi, S., Ikeda, T., Shinagawa, Y., Kunii, T.L., and Ueda, M.: Algorithms for Extracting Correct Critical Points and Constructing Topological Graphs from Discrete Geographical Elevation Data, Computer Graphics Forum, Vol. 14,
No. 3 (1995) pp. 181-192.

7 ) Dyn, N., Levin, D., and Rippa, S.: Data Dependent Triangulation for Piecewise Linear Interpolation, IMA Journal of $\mathrm{Nu}$ merical Analysis, Vol. 10 (1990) pp. 137-154.

8 ) Pfaltz, J.L.: Surface Networks, Geographical Analysis, Vol. 8 (1976) pp. 77-93.

9 ) Hoppe, H., DeRose, T., Duchamp, T., McDonald, J., and Stuetzle, W.: Mesh Optimization, In Proc. SIGGRAPH 93, Anaheim (1993) pp. 19-26.

10) Delaunay, B.: Sur la Sphere Vide, Izvestia Akademia Nauk SSSR, VII Seria, Otde lenie Mathematicheskii i Estestvennyka Nauk 7 (1934) pp. 793-800.

11) Cignoni, P., Rocchini, C., and Scopigno, R.: Metro: Measuring Error on Simplified Surfaces, Computer Graphics Forum, Vol. 17, No. 2 (1998) pp. 167-174.

12）武井利文, 松本秀樹, 村松一弘, 土肥俊 : 「大規模非定常数值 シミュレーションのためのリアルタイム可視化システム; NEC SX- 4 上での並列ベクトル処理性能」, 可視化情報学会 誌, Vol. 20, Suppl. 1 (2000) pp. 115-118; (JAERI-J 17741).

13) Staadt, O.G., and Gross, M.H.: Progressive Tetrahedralizations, In Proc. IEEE Visualization '98, Research Triangle Park (1998) pp. 397-402.

14) Cignoni, P., Costanza, D., Montani C., Rocchini, C., and Scopigno, R.: Simplification of Tetrahedral Meshes with Accurate Error, In Proc. IEEE Visualization 2000, Salt Lake City (2000) pp. 85-92. 